Bolm Inst. oceanogr., S Paulo, 40(1/2):101-115, 1992

\title{
Comparison of spawning patterns of the Brazilian sardine (Sardinella brasiliensis) and anchoita (Engraulis anchoita) in Ubatuba region, southern Brazil during 1985 through 1988
}

\author{
Yasunobu MATSUURA ${ }^{1}$; Henry L. SPACH ${ }^{2}$ \& Mário KATSURAGAWA ${ }^{1}$
}

\author{
1 - Instituto Oceanográfico da Universidade de São Paulo \\ (Caixa Postal 9075, 01065-970 Sāo Paulo, SP, Brasil) \\ 2 - Centro de Estudos do Mar, Universidade Federal do Paraná \\ (Av. Beira Mar s/n, 83255-000 Pontal do Sul, PR, Brasil)
}

\begin{abstract}
- Abstract: The Brazilian sardine (Sardinella brasiliensis) and anchoita (Engraulis anchoita) inhabit the southearstern Brazilian Bight. The former spawns at night (21:00-03:00) in coastal region during late-spring and summer, meanwhile, the latter spawns all year-around, mainly in coastal region during summer and in neritic region during winter. The spawning time of $E$. anchoita was observed all day long, but more intensively at night. During summer there occurs a strong vertical stratification of water masses. The spawning of $S$. brasiliensis occurs in surface mixed layer, while that of $E$. anchoita occurs beneath the thermocline inside the cool South Atlantic Central Water which occupies the bottom layer during late spring and summer. However, the sardine and anchovy egss and larvae were found inside both the upper tropical and lower cold water masses, but predominantly above thermocline in this region
\end{abstract}

- Descriptors: Spawning patterns, Environmental conditions, Vertical distribution, Sardinella brasiliensis, Engraulis anchoita, Ubatuba, Brazil.

- Descritores: Padrões de desova, Condições ambientais, Distribuição vertical, Sardinella brasiliensis, Engraulis anchoita, Ubatuba: SP.

\section{Introduction}

The main habitat of the Brazilian sardine (Sardinella brasiliensis) is confined within the southeastern Brazilian Bight (SEBB) between $22^{\circ} \mathrm{S}$ and $29^{\circ} \mathrm{S}$ where only one population of sardine is known. On the other hand the habitat of the anchoita (Engraulis anchoita) extends from the Gulf of San Jorge $\left(47^{\circ} \mathrm{S}\right)$ to Cabo Frio $\left(23^{\circ} \mathrm{S}\right)$ and there are at least three known subpopulations. The two southern subpopulations which inhabit Argentine and Uruguayan waters have a large population, varying from 4.0 to 6.2 million metric tons (Ciechomski \& Sánchez, 1988). Population biomass along the coast of Rio Grande do Sul has been estimated by serveral authors (Castello \& Habiaga, 1982; Castello, 1990; Lima, 1992). No biomass estimate was made on the northern subpopulation which inhabit the southeastern Brazilian Bight. There are two main spawning areas in Brazilian waters: one in the

Contr. no. 737 do Inst. oceanogr. da Usp. southern Brazil along the coast of Rio Grande do Sul State $\left(30^{\circ} \mathrm{S}-34^{\circ} \mathrm{S}\right)$ (Weiss \& Souza, 1977 ; Weiss \& Souto, 1988) and another in the SEBB where anchoita's spawning areas overlap with those of the Brazilian sardine (Nakatani, 1982; Spach, 1991).

Because of extreme adaptability, the anchoita can exploit both tropical waters in southern Brazil and cold Malvinas currents in Patagonia, extending its spawning area some $2800 \mathrm{~km}$ in the southwest Atlantic (Castello, 1990; Nakatami, 1982; Sánchez, 1990). In the southeastern Brazilian Bight, northern limit of spawning area, the anchoita spawns all year around, but the spawning in summer are concentrated inside the cold upwelled waters in coastal region and that in winter occurs in neritic region. The Brazilian sardine spawns only during late-spring and summer in coastal and neritic regions (Matsuura, 1990a).

To understand the reproductive strategies of sardine and anchoita which share the same habitat in the SEBB, we observed the seasonal spawning patterns of two species in the coastal region of Ubatuba and analyzed their annual variation in relation to environmental conditions. 


\section{Material and methods}

As a part of integrated oceanographic investigation on coastal ecosystem, six survey cruises have been conducted on the R/V "Prof. W. Besnard" in the coastal region of Ubatuba with station intervals of 5 and 10 n.m. during December 1985 through December 1988 (Fig. 1). The cruise of December 1987 was made with the R/V "Almirante Saldanha" and only nine Bongo net samples were taken.
Ichthyoplankton samples which were used to study horizontal distribution, were collected with the Bongo nets. The Bongo net was towed obliquely from surface down to $5 \mathrm{~m}$ above the bottom and again to surface with towing speed of about 2.5 knots.

Those for vertical distribution of eggs and larvae were collected with the MTD nets (Motoda, 1971) in three cruises conducted from December 1987 to December 1988. Firstly the depth of thermocline was determined using the bathythermograph. At each station, three or

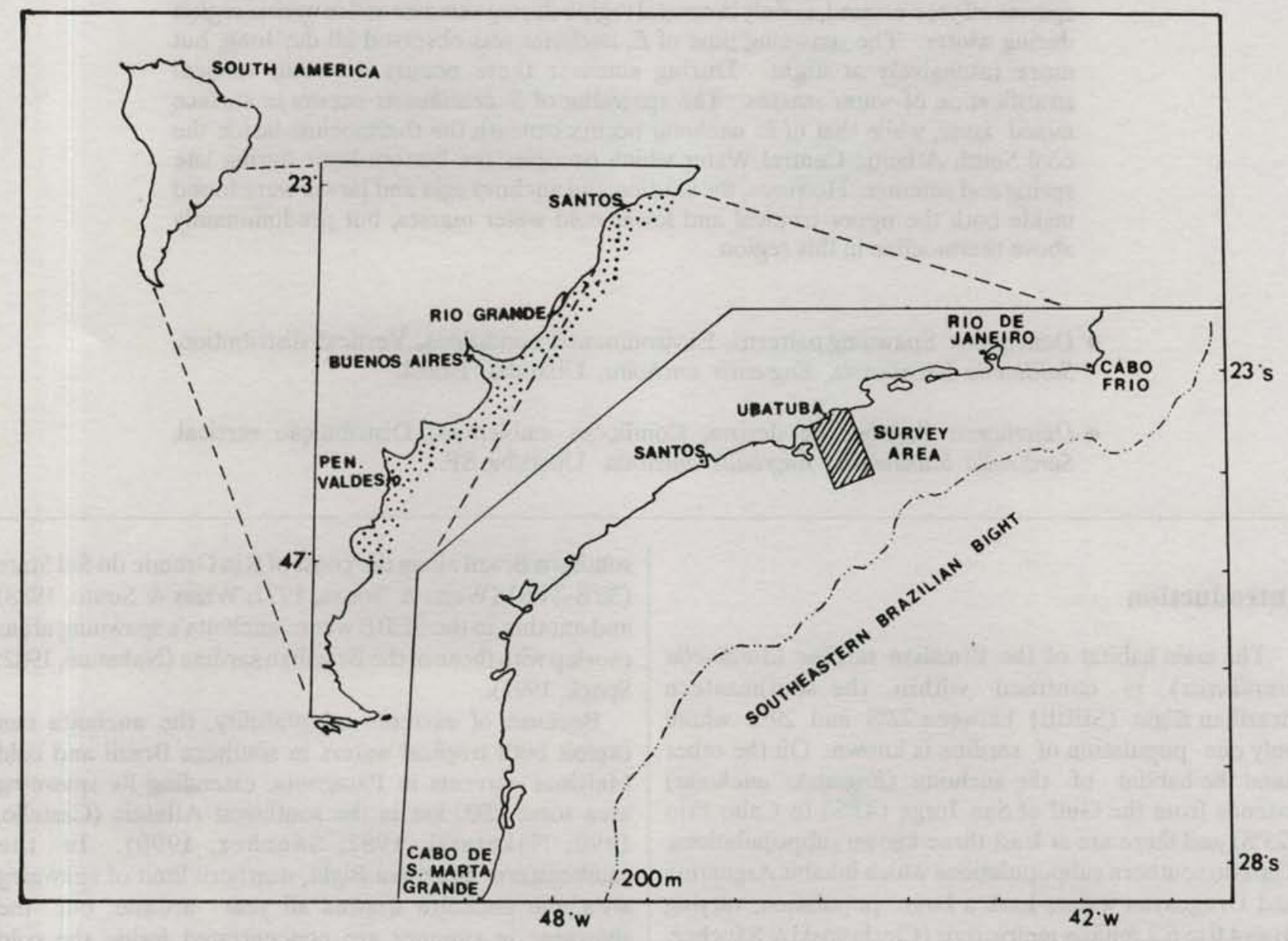

Fig. 1. Survey area in the southeastern Brazilian Bight and coastwise extension of anchoita habitat in the southwestern Atlantic. The habitats of anchoita are indicated with stippled area. 
four MTD nets were used at different water depths and towed horizontally for five minutes with a towing speed of about 2 knots. Towing depth of each net was calculated from wire angle and length. According to the sampling layer in relation to thermocline, all samples were classified into three depth zones: above, inside and beneath the thermocline.

All fish eggs and larvae were sorted from plankton samples, then sardine and anchoita eggs and larvae were identified based on literature descriptions (Houde \& Fore, 1973; Matsuura, 1971; 1975; Nakatani, 1982; Phonlor, 1984).

Numbers of eggs and larvae taken were transformed into the number per $1 \mathrm{~m}^{2}$ of sea surface using the following expression:

$$
y=d^{*} x / v,
$$

where $y=$ number of standardized eggs or larvae per 1 $\mathrm{n}^{2}$ of sea surface, $\mathrm{x}=$ number of eggs or larvae taken at station, $\mathrm{d}=$ maximum depth of haul (m) in Bongo net, or towing distance for the MTD nets, $v=$ volume of water filtered $\left(\mathrm{m}^{3}\right)$ measured by flow meter.

\section{Results}

\section{Distributions of sardine and anchoita eggs and larvae}

No sardine egg and larva were collected in the three winter cruises (July of 1986, 1987 and 1988) (Fig. 2). Sardine eggs were collected at several coastal stations in two summer cruises (December of 1985 and 1986), but no egg was found in December of 1987 and 1988 (Fig. 3). Abundance of sardine larvae in December 1985 was low and its distribution was limited to coastal stations, but it was more scattered over the survey area in December 1986 (Fig. 4). Of six coastal stations, only one station close to Caraguatatuba had sardine larvae. No sardine larva was found in December 1987 and occurrence in December 1988 was concentrated at neritic stations between 50 to 120 m depth contours.

In all four summer cruises (December from 1985 through 1988), anchoita eggs were collected only at the coastal stations (normally with less than $50 \mathrm{~m}$ depth). On the other hand, anchoita eggs were more abundant in neritic stations (deeper than $50 \mathrm{~m}$ ) in the winter cruises (July of 1986, 1987 and 1988).

Occurrences of anchoita larvae during the summer cruises were more wide scattered than that of eggs, but only small number of larvae were taken in nearshore stations (first row of coastal stations). During three winter cruises (July of 1986, 1987 and 1988) anchoita larvae were taken from all coastal and neritic stations with the exception of the nearshore stations (Fig. 5).

\section{Time of spawning of Engraulis anchoita}

All known clupeoid species have specific spawning time at about midnight or crepuscular time (Blaxter \& Hunter, 1982). To check the spawning time of Engraulis anchoita, we analyzed a relationship between the embryonic developmental stage and time of collection (Fig. 6). Embryonic developmental stage was determined following the criteria established by Moser \& Ahlstrom (1985). Recently spawned egg (Stage I) was scarce in the samples, but the Stage II eggs were collected at any time of day, indicating no specific spawning time (Spach, 1991).

Using the equation established between the hatching time and water temperature, developed by $L o(1985)$ and modified by Asano et al. (1991), spawning time of all anchoita eggs were back-calculated (Fig. 6). In spite of all-day spawning behavior of our anchoita, it is clear that the spawning during night was more intensive than in day time.

\section{Vertical distribution of eggs and larvae}

During three cruises (Dec. 1987, July \& Dec. 1988) the anchoita eggs and larvae were collected with the MTD nets in both summer and winter cruises and its abundance exceeded those of the sardine in summer cruises. Anchoita eggs and larvae were more abundant in coastal stations during summer and in neritic stations during winter. Anchoita eggs were more abundant in surface layer above the thermocline and only small number of anchoita eggs were collected inside and beneath the thermocline (Fig. 7). Anchoita larvae were more abundant in surface layer, but they also were found inside and beneath the thermocline.

Sardine eggs were more abundant in surface layer, but also found beneath the thermocline inside the SACW in coastal stations. On the other hand, sardine larvae were more abundant in the surface layer in neritic stations and no larva was found beneath the thermocline (Fig. 7).

\section{Annual variation of spawning intensity}

To estimate total number of eggs spawned in the area we must obtain natural mortality rate of eggs. Because of small number of positive stations in which one or more eggs were found, we could not obtain this data. Therefore, for comparative purpose, we estimated total number of eggs in the survey area without correction by mortality rate (Table 1).

Proportion of positive stations of anchoita eggs in winter cruises exceed that of summer cruises and mean number of anchoita eggs was also much higher than that of summer cruises except December 1988 cruise. Proportions of positive station of anchoita larvae were always high in both summer and winter, but the mean numbers of larvae per square meter were relatively low (Fig. 8). 


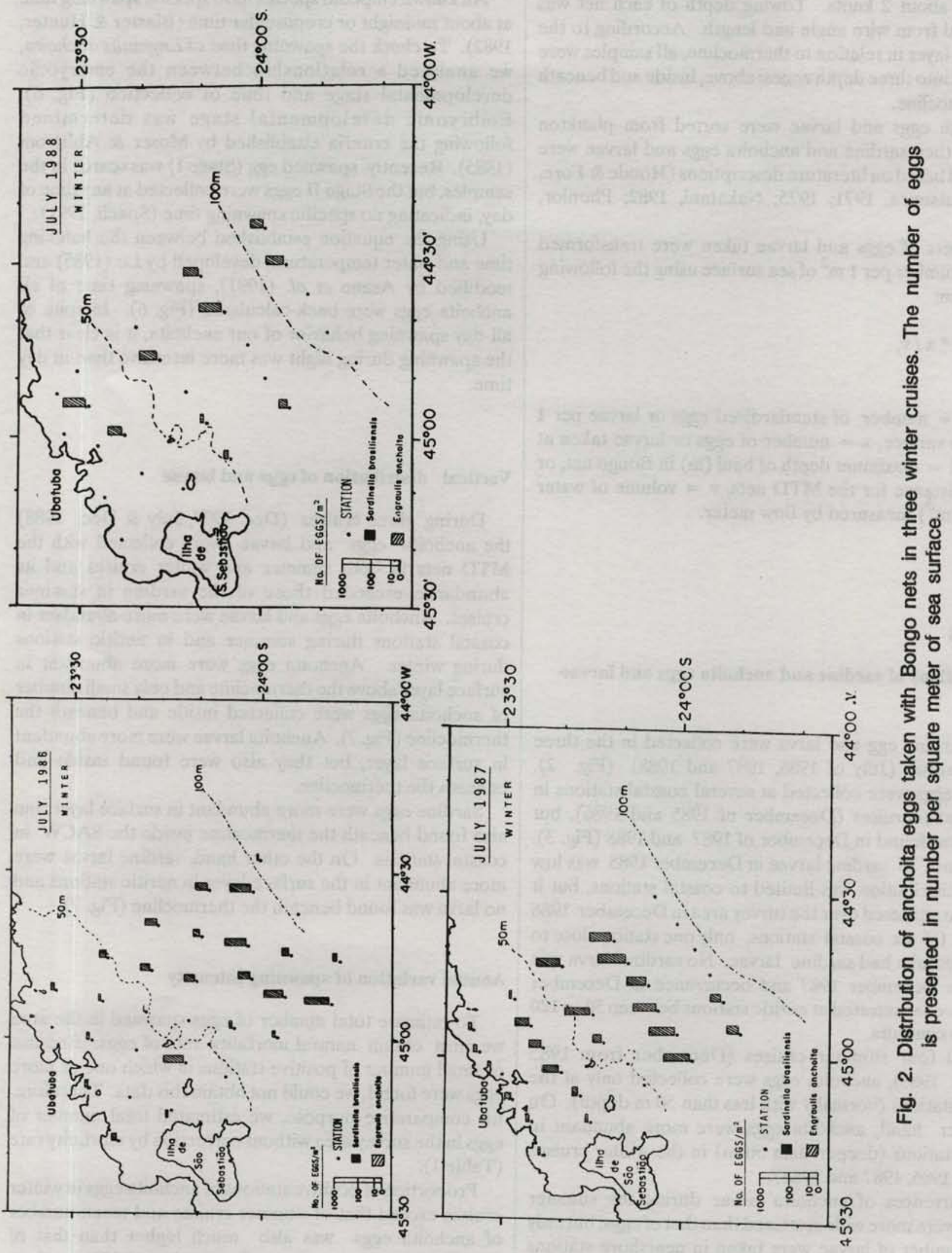




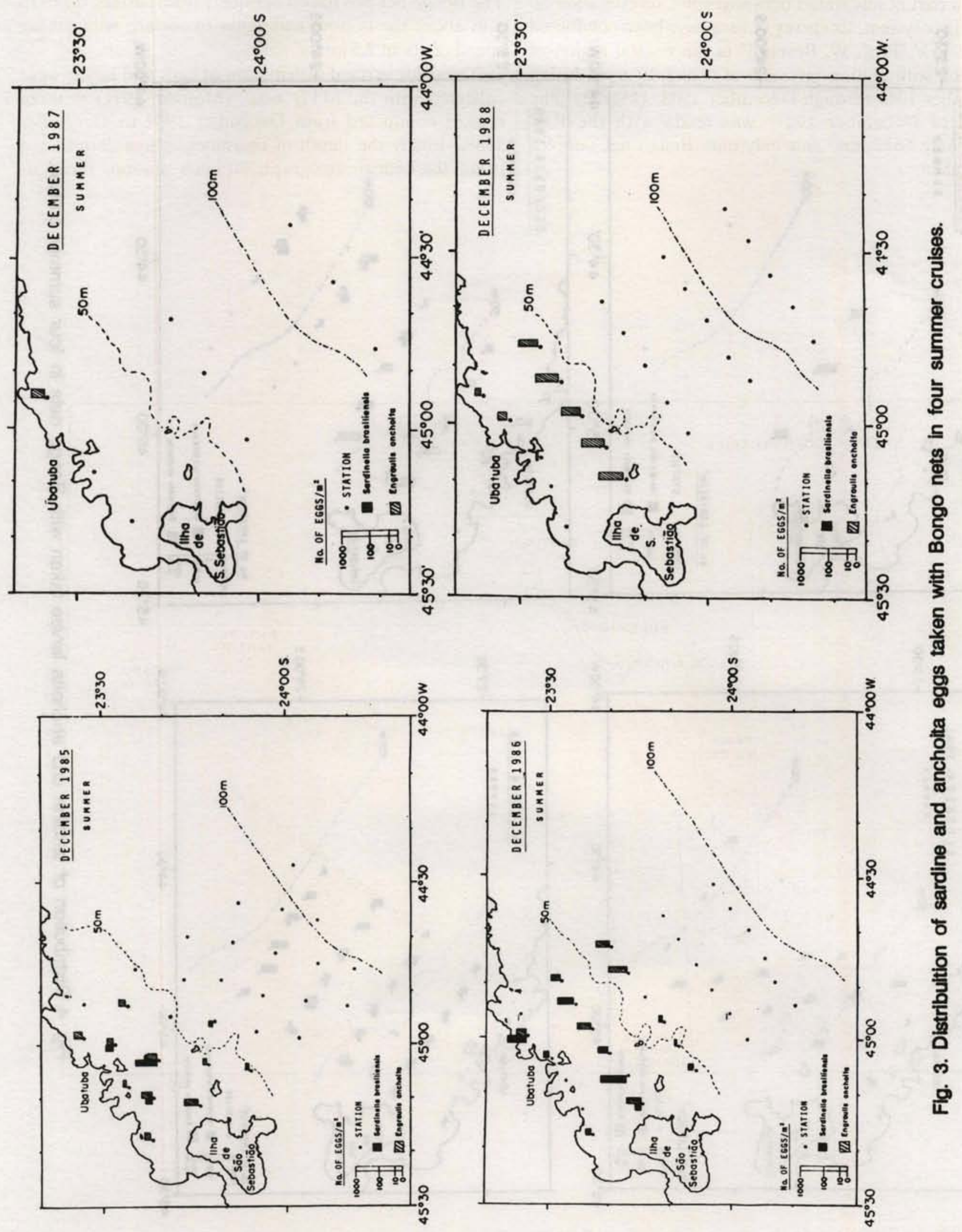




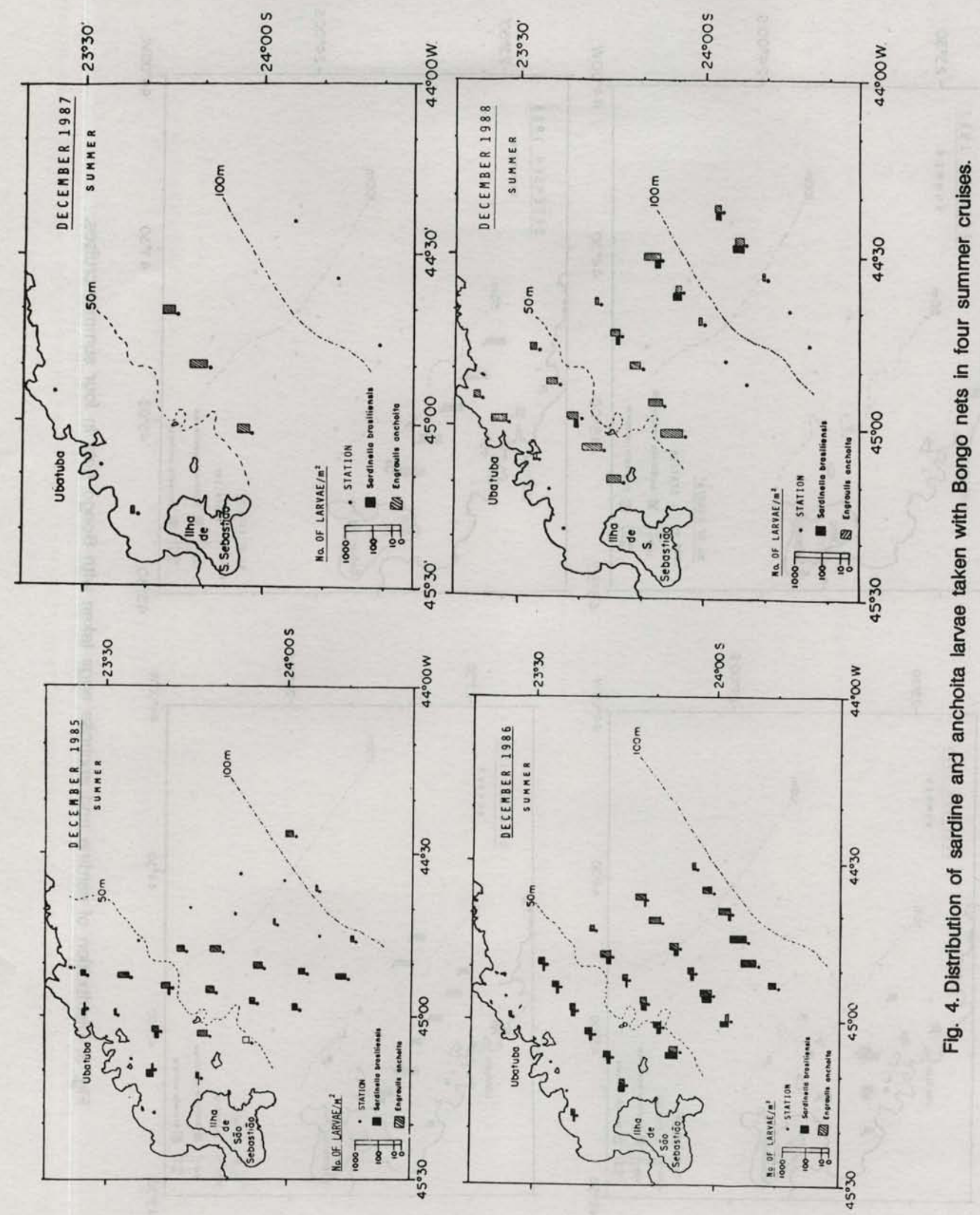




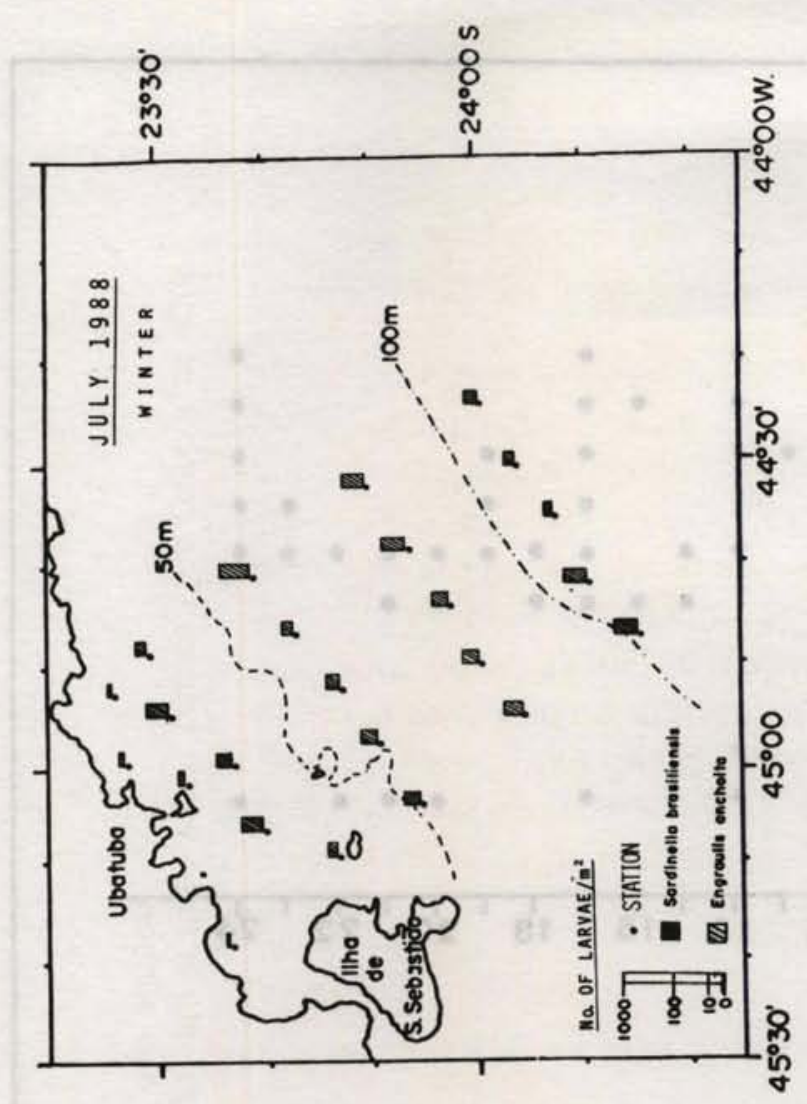

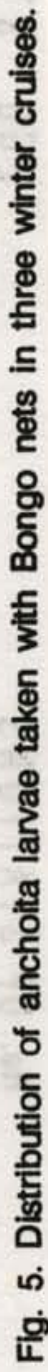

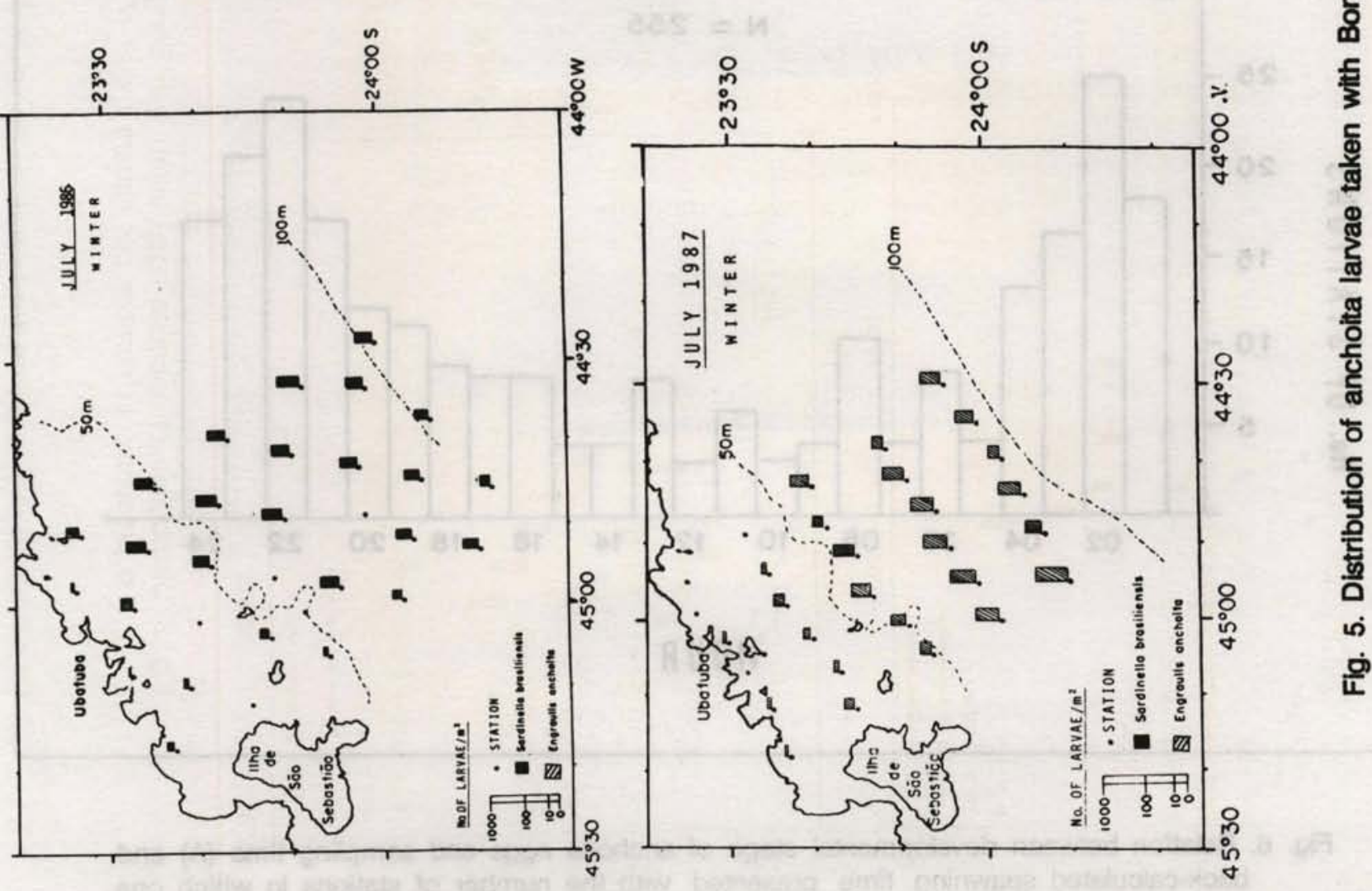




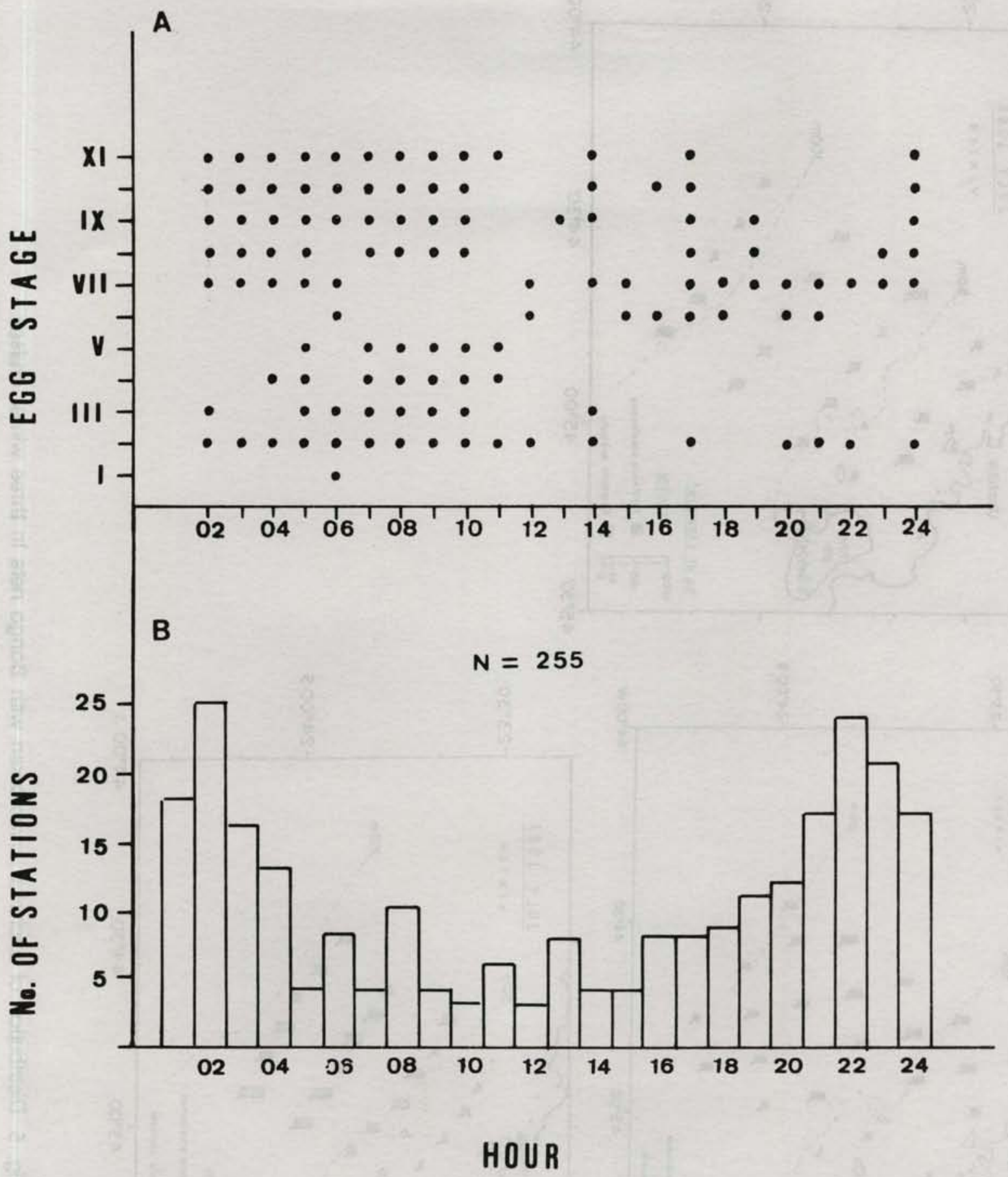

Fig. 6. Relation between developmental stage of anchoita eggs and sampling time (A) and back-calculated spawning time presented with the number of stations in which one or more anchoita eggs of different developmental stage, were found (B). 

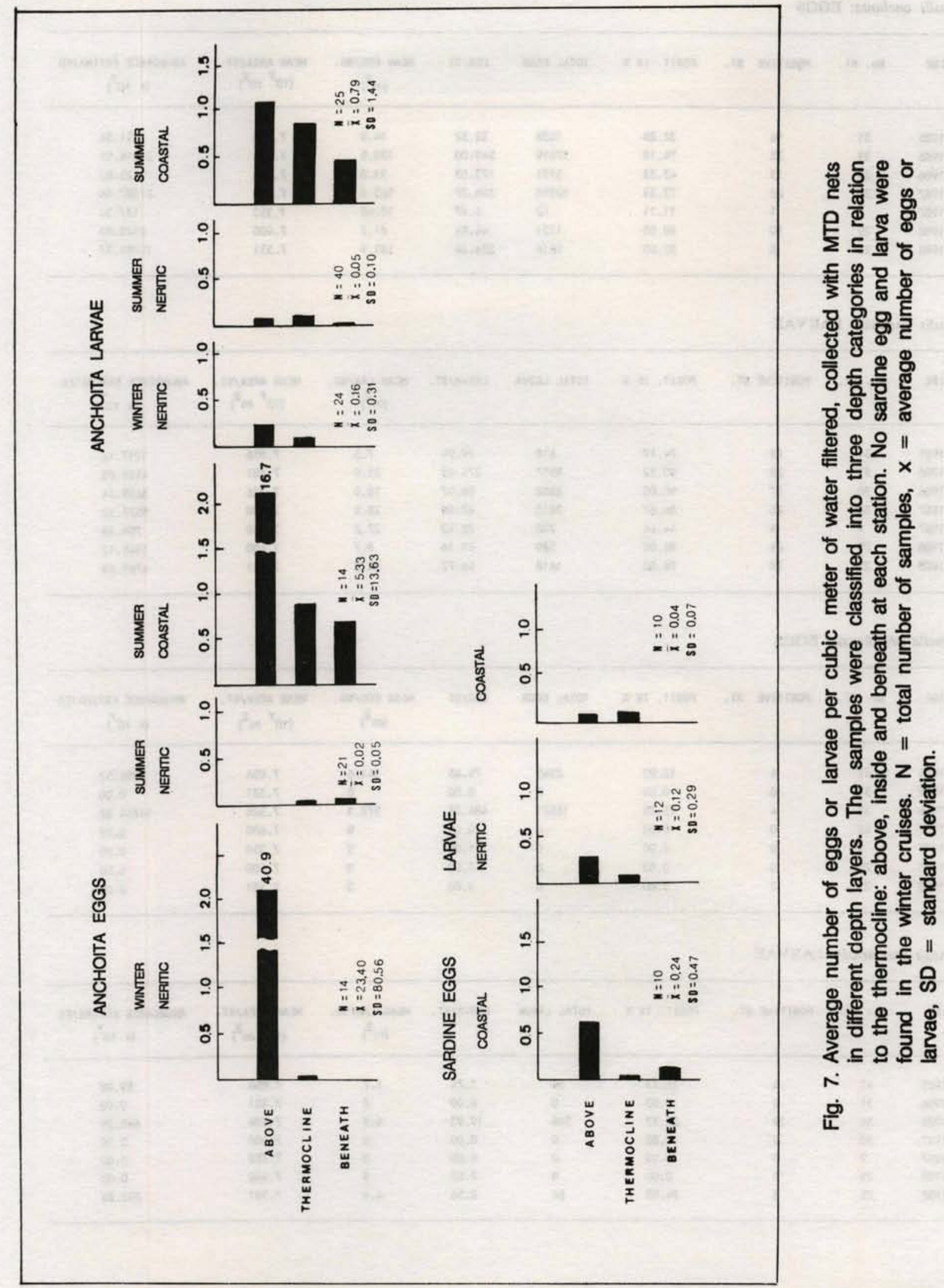
Table 1. Estimation of sardine and anchoita eggs and larvae in Ubatuba collected with Bongo nets

Engraulis anchoita: EGGS

\begin{tabular}{|c|c|c|c|c|c|c|c|c|c|}
\hline CRUISE & No. ST. & PQQSITIVE & sT. & POSIT. II X & TOTAL EGGS & $E G G / S T$ & $\begin{array}{c}\text { MEAN EGG/SQ. } \\
\left(m^{2}\right)\end{array}$ & $\begin{array}{l}\text { NEAN AREA/ST. } \\
\left(10^{7} \mathrm{~m}^{2}\right)\end{array}$ & $\begin{array}{l}\text { NBUWDANCE ESTIMATED } \\
\qquad\left(\times 10^{7}\right)\end{array}$ \\
\hline DEC. 1985 & 31 & 10 & & 32.26 & 1053 & 33.32 & 14.9 & 7.056 & 1051.34 \\
\hline JUL. 1986 & 31 & 23 & & 74.19 & 17019 & 549.00 & 128.5 & 7.381 & 21814.55 \\
\hline DEC. 1986 & 30 & 13 & & 43.33 & 5191 & 173.03 & 53.8 & 7.326 & 5123.80 \\
\hline JUL. 1987 & 30 & 22 & & 73.33 & 10388 & 346.27 & 163.2 & 7.600 & 27287.04 \\
\hline DEC. 1987 & 9 & 1 & & 11.11 & 42 & 4.67 & 18.68 & 7.350 & 137.30 \\
\hline JUL. 1988 & 25 & 10 & & 40.00 & 1121 & 44.84 & 61.2 & 7.400 & 4528.80 \\
\hline DEC. 1988 & 25 & 8 & & 32.00 & 5616 & 224.64 & 183.9 & 7.331 & 10785.37 \\
\hline
\end{tabular}

Engraulis anchoita: LARVAE

\begin{tabular}{|c|c|c|c|c|c|c|c|c|}
\hline CRUISE & No. ST. & POSITIVE ST. & POSIT. IN $\mathrm{x}$ & TOTAL LARVA & LARVA/ST. & $\begin{array}{c}\text { MEAN LAR/SO. } \\
\left(m^{2}\right)\end{array}$ & $\begin{array}{l}\text { NENH AREA/ST. } \\
\left(10^{7} \mathrm{~m}^{2}\right)\end{array}$ & $\begin{array}{c}\text { ABUNDANCE ESTIMATED } \\
\qquad\left(\times 10^{7}\right)\end{array}$ \\
\hline DEC. 1985 & 31 & 23 & 74.19 & 618 & 19.94 & 7.5 & 7.056 & 1217.16 \\
\hline JUL. 1986 & 31 & 28 & 90.32 & 8557 & 276.03 & 21.9 & 7.381 & 4526.03 \\
\hline DEC. 1986 & 30 & 27 & 90.00 & 2882 & 96.07 & 18.5 & 7.326 & 3659.34 \\
\hline JL. 1987 & 30 & 26 & 86.67 & 2010 & 67.00 & 28.2 & 7.600 & 5572.32 \\
\hline DEC. 1987 & 9 & 4 & 44.44 & 200 & 22.22 & 27.2 & 7.350 & 799.68 \\
\hline JUL. 1988 & 25 & 24 & 96.00 & 529 & 21.16 & 8.7 & 7.400 & 1545.12 \\
\hline DEC. 1988 & 25 & 19 & 76.00 & 1418 & 56.72 & 34.2 & 7.331 & 4763.68 \\
\hline
\end{tabular}

Sardinella brasiliensis: EGGS

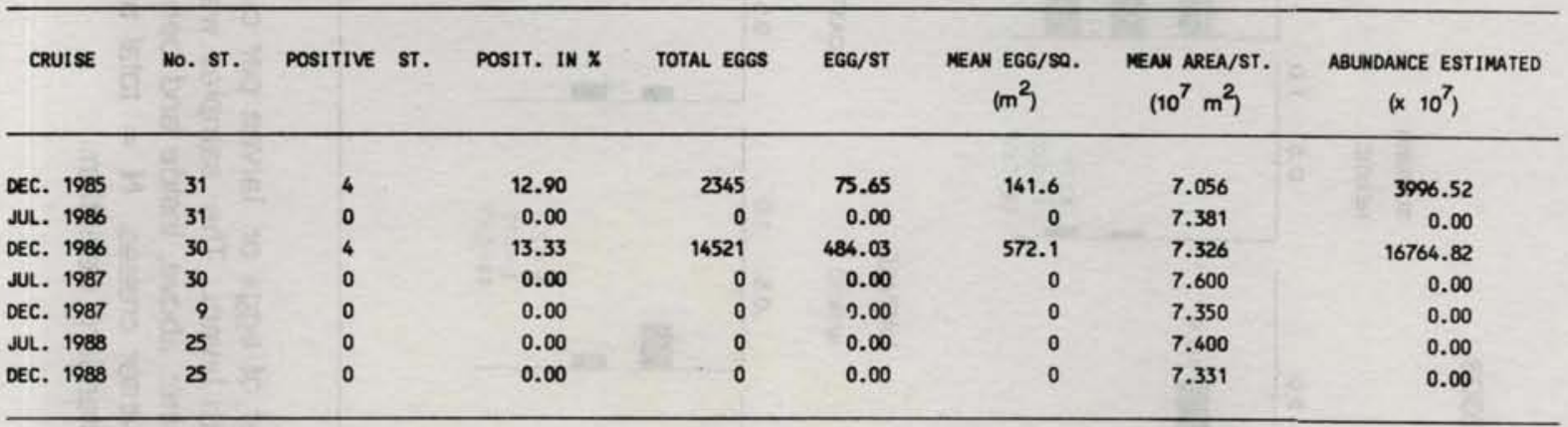

Sardinella brasiliensis: LARVAE

\begin{tabular}{|c|c|c|c|c|c|c|c|c|c|}
\hline CRUISE & No. ST. & POSITIVE ST. & POSIT. IN X & TOTAL & LARVA & LARVA/ST. & $\begin{array}{c}\text { MEAN LAR/SO. } \\
\left(m^{2}\right)\end{array}$ & $\begin{array}{c}\text { MEAN AREA/ST. } \\
\left(10^{7} \mathrm{~m}^{2}\right)\end{array}$ & $\begin{array}{l}\text { ABUNDANCE ESTIMATED } \\
\qquad\left(\begin{array}{c}\times \\
10^{7}\end{array}\right)\end{array}$ \\
\hline DEC. 1985 & 31 & 5 & 16.13 & 54 & & 1.74 & 1.7 & 7.056 & 59.98 \\
\hline JUL. 1986 & 31 & 0 & 0.00 & $=$ & 0 & 0.00 & 0 & 7.381 & 0.00 \\
\hline DEC. 1986 & 30 & 19 & 63.33 & 598 & & 19.93 & 4.6 & 7.326 & 640.29 \\
\hline JUL. 1987 & 30 & 0 & 0.00 & $=$ & & 0.00 & 0 & 7.600 & 0.00 \\
\hline DEC. 1987 & 9 & 0 & 0.00 & 0 & & 0.00 & 0 & 7.350 & 0.00 \\
\hline JUL. 1988 & 25 & 0 & 0.00 & 0 & & 0.00 & 0 & 7.400 & 0.00 \\
\hline DEC. 1988 & 25 & 6 & 24.00 & 64 & & 2.56 & 4.6 & 7.331 & 202.34 \\
\hline
\end{tabular}




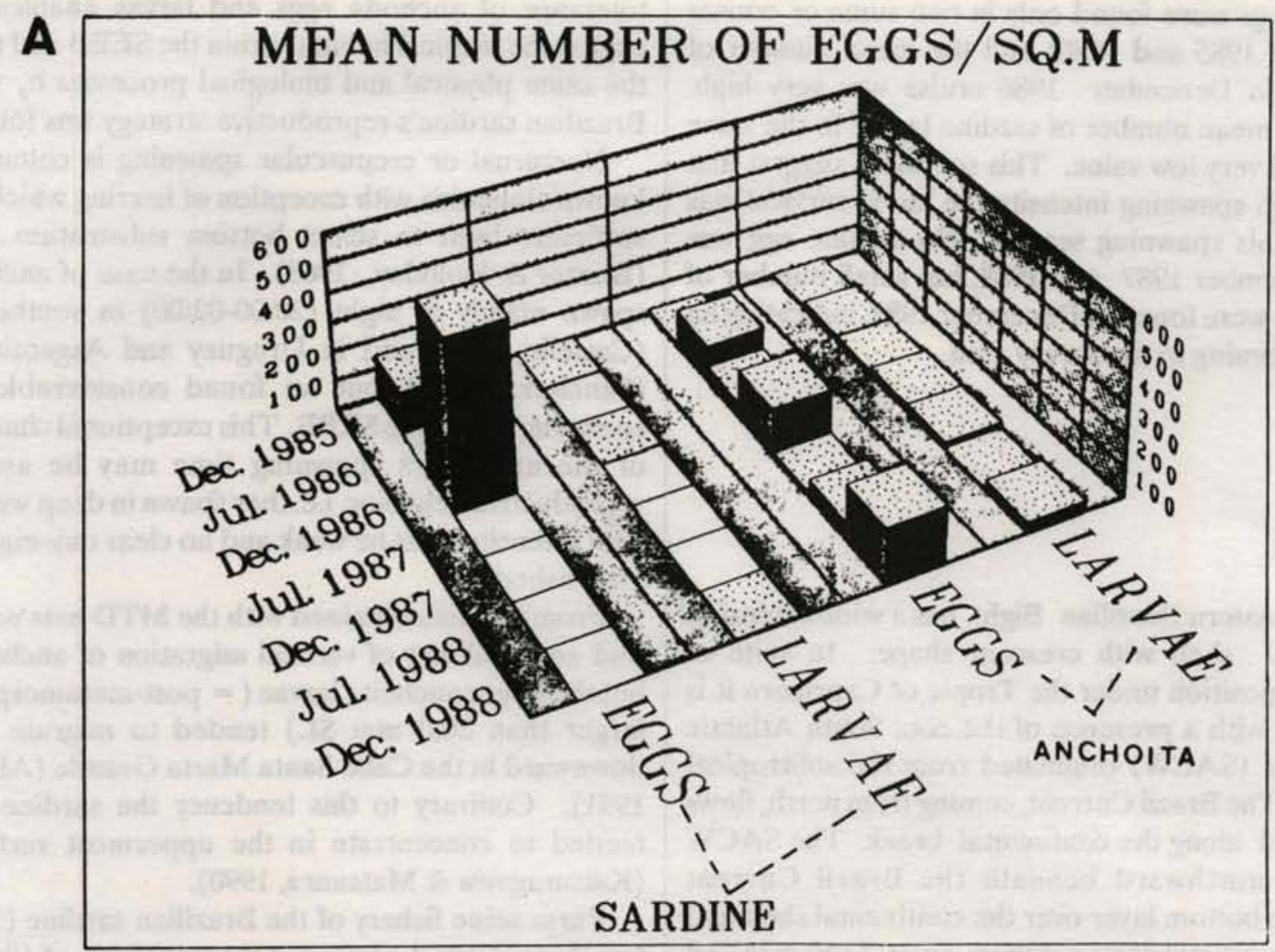

B

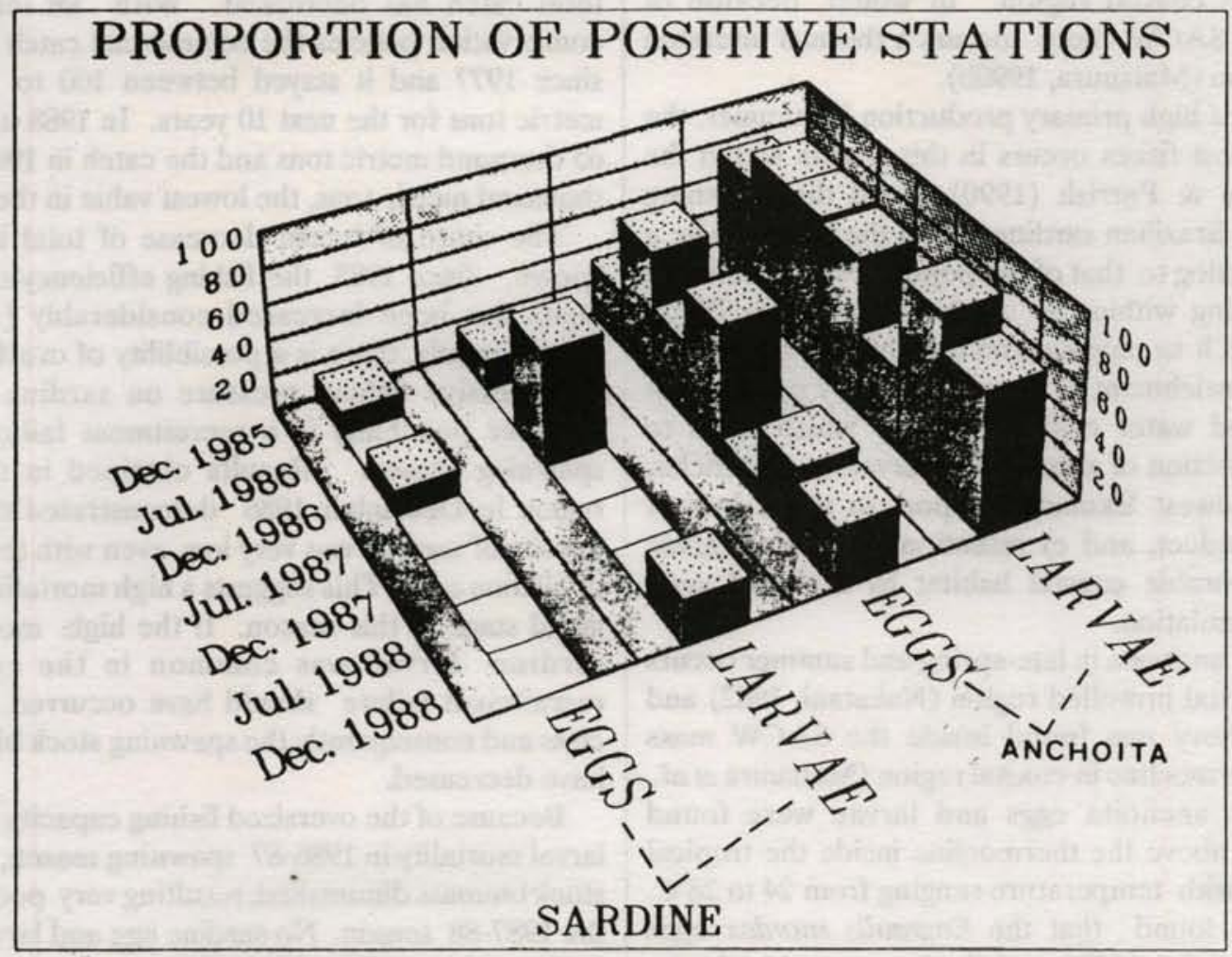

Fig. 8. Average number of sardine and anchoita eggs or larvae in each survey cruise (A) and proportion of positive stations in which one or more eggs or larvae were found, in each survey cruise (B). 
Sardine eggs were found only in two summer cruises (December of 1985 and 1986) and the mean number of sardine eggs in December 1986 cruise was very high. However, the mean number of sardine larvae in the same cruise showed very low value. This seems to suggest that in spite of high spawning intensity the larval survival was not good in this spawning season. No sardine egg was found in December 1987 and 1988, but small number of sardine larvae were found in December 1988, indicating an incidental spawning in the survey area.

\section{Discussion}

The southeastern Brazilian Bight has a wide extension of continental shelf with crescent shape. In spite of geographical position under the Tropic of Capricorn it is characterized with a presence of the cool South Atlantic Central Water (SACW) originated from the subtropical convergence. The Brazil Current, coming from north, flows southwestward along the continental break. The SACW which flows northward beneath the Brazil Current penetrates the bottom layer over the continental shelf and reaches to the coastal region during austral summer and retreats to offshore in winter (Matsuura, 1986). The contrast with the overlying warm, tropical surface water results in strong vertical stratification in summer. Presence of the SACW in euphotic zone caused high primary production in coastal region. In winter, because of absence of the SACW, there occurs a thermal inversion in coastal region (Matsuura, 1990b).

As a result of high primary production in summer, the spawning of most fishes occurs in this season within the SEBB. Bakun \& Parrish (1990) found the spawning strategy of the Brazilian sardine within the SEBB to be a nearly exact analog to that of the population of California sardine spawning within the southern California Bight. They attributed it to physical and biological processes in the Bight: a) enrichment of coastal water by presence of the SACW and water column stability which leads to adequate production of appropriate larval food particles, b) coastwise lowest Ekman trasnport to avoid loss of spawning product, and c) retention of sardine larvae within the favorable coastal habitat by a closed gyral geostrophic circulation.

Spawning of anchoita in late-spring and summer occurs in the cool coastal upwelled region (Nakatani, 1982) and the adult anchovy was found inside the SACW mass beneath the thermocline in coastal region (Matsuura et al., 1985), but the anchoita eggs and larvae were found predominantly above the thermocline inside the tropical coastal waters with temperature ranging from 24 to $28^{\circ} \mathrm{C}$. Brewer (1976) found that the Engraulis mordax eggs hatched between $8.5-28.5^{\circ} \mathrm{C}$ and the larvae could tolerate a temperature range from 7 to $30^{\circ} \mathrm{C}$ in the California Current region. Thus, despite of confinement of adult anchoita inside the SACW mass, the high temperature tolerance of anchoita eggs and larvae enables them to exploit the tropical habitat within the SEBB and they enjoy the same physical and biological processes $b_{y}$ which the Brazilian sardine's reproductive strategy was founded.

Nocturnal or crepuscular spawning is common in all known clupeoids with exception of herring which requires sufficient light to select bottom substratum to spawn (Blaxter \& Holliday, 1963). In the case of anchoita they spawn mainly at night (20:00-02:00) in southern Brazil (Castello, 1990) and in Uruguay and Argentine waters (Sánchez, 1990), but we found considerable daytime spawning within the SEBB. This exceptional characteristic of the anchoita's spawning time may be assigned to reproductive behabior, i.e. they spawn in deep water where light intensity must be weak and no clear day-night cycle is established.

From the data obtained with the MTD nets we failed to find any tendency of vertical migration of anchoita larva, but the larger anchoita larvae (= post-metamorphic stage, larger than $20.0 \mathrm{~mm} \mathrm{SL}$ ) tended to migrate vertically downward in the Cabo Santa Marta Grande (Alheit et al., 1991). Contrary to this tendency the sardine juveniles tended to concentrate in the uppermost surface layer (Katsuragawa \& Matsuura, 1990).

Purse seine fishery of the Brazilian sardine (Sardinella brasiliensis) which started at the beginning of 1960 s is one of the most important fisheries in the southern Brazil. With an increase of number of fishing boats, total landing also has increased and achieved the record catch of 230 thousand metric tons in 1973. Following three years the total catch has decreased. With an introduction of conservation policies the commercial catch has stabilized since 1977 and it stayed between 100 to 150 thousand metric tons for the next 10 years. In 1988 it decreased to 65 thousand metric tons and the catch in 1990 was only 32 thousand metric tons, the lowest value in the last 25 years.

The cause of recent decrease of total landing is not known. Since 1985 the fishing efficiency of purse seine boats has been increased considerably (Anon. 1991). Consequently, there is a possiblility of overfishing caused by excessive fishing pressure on sardine population. Another possibility is a recruitment failure in 1986-87 spawning season. Results obtained in the Ubatuba region in December 1986 demonstrated that the larval density of sardine was very low, even with the high density of sardine eggs. This suggests a high mortality rate of early larval stage in this season. If the high mortality rate of sardine larvae was common in the entire SEBB, recruitment failure should have occurred in 1987 year class and consequently the spawning stock biomass should have decreased.

Because of the oversized fishing capacity or by the high larval mortality in 1986-87 spawning season, the spawning stock biomass diminished, resulting very poor spawning in the 1987-88 season. No sardine egg and larva were found in December 1987 cruise (Figs 3 and 4) and the Egg Production Method cruise conducted in January 1988 also confirmed very low spawning intensity within the SEBB (Katsuragawa, in prep.). 
There is no direct evidence to explain the high mortality of sardine larvae in December 1986. Matsuura (1990b) demonstrated that the high primary production in summer was caused by two physical processes: a) penetration of the SACW in euphotic zone of coastal region, and b) injection of nutrient rich SACW in surface layer by cyclonic movement of vortex in neritic zone. Since the high primary production in coastal region of the SEBB depends on injection of nutrients in euphotic zone by the SACW or by vortex, the intensity of penetration of the SACW in coastal region may have some relation with larval mortality. The penetration of the SACW in December 1986 was very weak and failed to reach a coastal region (Matsuura, 1990b). We also found no vortex in neritic region in December 1986. Thus, we speculate that the low primary production and consequent low density of food particles in coastal waters might have resulted high mortaly of sardine larvae

\section{Conclusions}

1) Spawning of the Brazilian sardine (Sardinella brasiliensis) and anchoita (Engraulis anchoita) were investigated based on the ichthyoplankton data collected in the coastal region of Ubatuba during 1985-1988.

2) No sardine egg and larva were found in the three winter cruises (July 1986, 1987 and 1988), but the anchoita eggs and larvae were collected both in winter and summer cruises.

3) A fairly large amount of sardine eggs were found in survey area in the first two summer cruises (December 1985 and 1986), but no egg was found in the last two summer cruises (December 1987 and 1988).

4) Occurrences of anchoita eggs and larvae in summer cruises were concentrated in costal region (less than $50 \mathrm{~m}$ contour), but they were more abundant in neritic region in winter cruises.

5) Sardine spawning took place in the upper mixing layer at night (21:00-03:00), as any know clupeoid fishes, but the spawning of anchoita was observed below the thermocline all day long with high intensity at night. The sardine and anchoita eggs and larvae were found inside both the upper tropical water and lower cold water masses, but predominantly above thermocline.

6) Intensity of penetration of cold South Atlantic Central Water in bottom layer during December 1986 was very weak and failed to reach a coastal region. The high mortality of sardine larvae in that season was attributed to absence of the nutrient rich SACW in the coastal region.

\section{Resumo}

Neste trabalho são analisados os padrōes sazonais de desova da sardinha-verdadeira, Sardinella brasiliensis, e da anchoita, Engraulis anchoita, baseado em dados coletados em águas costeiras de Ubatuba (SP), entre 1985 e 1988.

Ambas as espécies habitam a costa sudeste do Brasil. A primeira efetua desova durante a noite $(21: 00-23: 00 \mathrm{~h})$ na regiāo costeira durante o fim da primavera e o verāo, enquanto que a segunda desova durante todo o ano, principalmente na região costeira durante o verão e na regiāo nerítica durante o inverno. A desova da anchoita foi observada ao longo de todo o dia, porém com mais intensidade à noite.

No verão, ocorre uma forte estratificação vertical das massas d'água. A desova da sardinha-verdadeira ocorre na camada superficial de mistura, enquanto que a da anchoita ocorre abaixo da termoclina, nas águas frias da "Água Central do Atlântico Sul" (ACAS), que ocupam as camadas do fundo durante o verão. Entretanto, ovos e larvas de ambas as espécies foram encontrados tanto na camada superior, de água tropical, como na camada inferior, de água fria, embora predominantemente acima da termoclina.

\section{Acknowledgements}

Integrated oceanographic investigation on coastal ecosystem in Ubatuba was financed by the CIRM (Comissão Interministerial para os Recursos do Mar). Special thanks go to Kazuko Suzuki who prepared most of the figures and tables. The authors received research fellowship of the CNPq (Conselho Nacional de Desenvolvimento Científico e Tecnológico) during this study.

\section{References}

ALHEIT, J.; CIECHOMSKI, J. de; DJURFELDT, L.; EBEL, C.; EHRLICH, M.; ELGUE, J. C.; MANTERO, G.; MATSUURA, Y.; MIANZAN, H.; NELLEN, W.; ODEBRECHT, C.; RAMIREZ, F.; SÁNCHEZ, R.; SHAFFER, G. \& VINAS, M. D. 1991. SARP studies on southwest Atlantic anchovy, Engraulis anchoita, off Argentine, Uruguay and Brazil. ICES C. M., L:46, Session V.

ANON. 1991. Relatório da reuniāo do Grupo Permanente de Estudos sobre Sardinha. CEPSUL, IBAMA, Itajaí, SC. 15p. 
ASANO, K.; MATSUURA, Y. \& KATSURAGAWA, M. 1991. Daily egg production of the Brazilian anchovy, Engraulis anchoita. Bull. Fac. Bioresources, Mie Univ., 6:47-55.

BAKUN, A. \& PARRISH, R. H. 1990. Comparative studies of coastal pelagic fish reproductive habitats: the Brazilian sardine (Sardinella aurita). J. Cons. int. Explor. Mer, 46:269-283.

BLAXTER, J.H. S. \& HOLLIDAY, F. G. T. 1963. The behaviour and physiology of herring and other clupeids. Adv. mar. Biol., 1:261-393.

\& HUNTER, J. R. 1982. The biology of clupeoid fishes. Adv. mar. Biol., 20:1-223.

BREWER, G. D. 1976. Thermal tolerance and resistance of the northern anchovy Engraulis mordax. Fishery Bull. natn. mar. Fish. Serv., U.S., 74:1-8.

CASTELlO, J. P. 1990. Synopsis on the reproductive biology and early life history of Engraulis anchoita, and related environmental conditions in Brazilian waters. IOC Workshop Rep., 65, Annex 7. p. 1-7.

\& HABIAGA, R.P. 1982. Resultados preliminares da avaliaçāo de pequenos peixes pelágicos usando técnicas hidro-acústicas na plataforma continental do Rio Grande do Sul. In: SIMPÓSIO NAVAL DESONAR, Arraial do Cabo, 1982. Anais. Rio de Janeiro, Instituto de Pesquisas da Marinha. v.2, art. 19.

CIECHOMSKI, J. D. de \& SÁNCHEZ, R. P. $1988^{\circ}$ Análisis comparativo de las estimaciones de biomasa de la anchoita (Engraulis anchoita) en el Atlantico Sudoccidental en diferentes año y con distintas metodologias. Publnes Com. Téc. mix. Frente mar., 4:117-132.

HOUDE, E. D. \& FORE, P. L. 1973. Guide to identity of eggs and larvae of some Gulf of Mexico clupeid fishes. Fla mar. Res. Lab., Leafl. Ser., 4(23):1-14.

KATSURAGAWA, M. \& MATSUURA, Y. 1990. Comparison of the diel and spatial distribution patterns of ichthyoplankton and ichthyoneuston in the southeastern Brazilian Bight. Bolm Inst. oceanogr., S Paulo, 38(2):133-146.

LIMA JR., I. D. 1992. Distribuiçāo e abundância de anchoita (Engraulis anchoita) em relaçāo aos processos oceanográficos na plataforma continental do sul do Brasil. MSc. dissertation. Fundaçāo Universidade do Rio Grande. 64pp. Unpubl.
LO, N. C. H. 1985. A model for temperature-dependent northern anchovy egg development and automated procedure for the assignment of age to staged eggs. In: Lasker, R., ed. An egg production method for estimating spawning biomass of pelagic fish: application to the northern anchovy, Engraulis mordax. Tech. Rep. natn. mar. Fish. Serv., U.S., 36:43-50.

MATSUURA, Y. 1971. A study of the life history of Brazilian sardine, Sardinella aurita. I. Distribution and abundance of sardine eggs in the region of Ilha Grande, Rio de Janeiro. Bolm Inst. oceanogr., S Paulo, 20:33-60.

1975. A study of the life history of Brazilian sardine, Sardinella brasiliensis. III. Development of sardine larvae. Bolm Inst. oceanogr., S Paulo, 24:17-29.

1986. Contribuiçāo ao estudo sobre estrutura oceanografica da região sudeste entre Cabo Frio(RJ) e Cabo de Santa Marta Grande (SC). Ciênc. Cult., S Paulo, 38(8):1439-1450.

1990a. Synopsis on the reproductive biology and early life history of the Brazilian sardine, Sardinella brasiliensis, and related environmental conditions. IOC Workshop Rep., 65, Annex 8. p.1-8.

1990b. Rational utilization of coastal ecosystem in tropics: integrated investigatioin of coastal ecosystem in Ubatuba region. In: SIMPOSIO DE ECOSSISTEMAS DA COSTA SUL E SUDESTE BRASILEIRA: ESTRUTURA, FUNÇĀO E MANEJO, 2., Águas de Lindóia, 1990. São Paulo, Academia de Ciências do Estado de São Paulo. v. 1, p.47-52.

; AMARAL, J. C.; TAMASSIA, S. T. J. \& SATO, G. 1985. Ocorrência de cardumes de peixes pelágicos e a estrutura oceanográfica da regiāo entre Cabo de Sāo Tomé (RJ) e Cananéia (SP) em janeiro-fevereiro/1979. Sér. Doc. téc., PDP/SUDEPE, Brasilia, 33:3-73.

MOSER, H. G. \& AHLSTROM, E. H. 1985. Staging anchovy eggs. In: Lasker, R., ed. An egg production method for estimating spawning biomass of pelagic fish: application to the northern anchovy, Engraulis mordax. Tech. Rep. natn. mar. Fish. Serv., U.S., 36:7-15.

MOTODA, S. 1971. Devices of simple plankton apparatus V. Bull. Fac. Fish. Hokkaido Univ., 22(2):101-106. 
NAKATANI, K. 1982. Estudos sobre os ovos e larvas de Engraulis anchoita (Hubbs \& Marini, 1935) (Teleostei: Engraulidae) coletados na regiāo entre Cabo Frio $\left(23^{\circ} \mathrm{S}\right)$ e Cabo de Santa Marta Grande $\left(29^{\circ} \mathrm{S}\right)$. MSc. dissertation. Universidade de São Paulo, Instituto Oceanográfico. 89pp. Unpubl.

PHONLOR, G. 1984. Morfologia e biologia dos ovos de Engraulidae do sul do Brasil (Teleostei, Clupeiformes). Rev. Brasil. Biol. 44(4):467-487.

SÁNCHEZ, R. P. 1990. Synopsis on the reproductive biology and early life history of Engraulis anchoita and related environmental conditions in Argentine waters. IOC Workshop Rep., 65, Annex 5. p. 1-49.

SPACH, H. L. 1991. Estudo comparativo da distribuição espaço-temporal e de padrōes de agregação de ovos e larvas de Harengula jaguana, Sardinella brasiliensis (Clupeidae: Osteichthyes) e Engraulis anchoita (Engraulidae: Osteichthyes) na costa sudeste do Brasil. Dr. theses. Universidade de São Paulo, Instituto Oceanográfico. 87pp + 135 tabs +90 figs. Unpubl.
WEISS, G. \& SOUZA, J. A. F. 1977. Desova invernal de Engraulis anchoita na costa sul do Brasil em 1970 e 1976. Atântica, Rio Grande, 7:5-24.

\& SOUTO, C. F. 1988. Ictioplâncton marinho da costa sul do Brasil. In: SIMPOSIO DA FURG SOBRE PESQUISA PESQUEIRA, 1., Rio Grande, 1988. Resumo. Rio Grande, Fundação Universidade do Rio Grande. p.43.

(Manuscript received 20 August 1992; revised 1 December 1992; accepted 10 December 1992) 